\title{
Penilaian Pelaksanaan Kurikulum Tingkat Satuan Pendidikan (KTSP) Berdasarkan Stake's Countenance Model Bagi Mata Pelajaran Bahasa Arab di Madrasah Aliyah GUPPI, Kota Jambi 2012/2013
}

\section{Evaluation on the Implementation of KTSP Curriculum Based on Stake's Countenance Model in Arabic Subject in the Madrasah Aliyah GUPPI Kota Jambi 2012/2013}

\author{
BUDI SANJAYA* \& MAIMUN AQSHA LUBIS ${ }^{1}$
}

\begin{abstract}
Level of Education Curriculum Unit (KTSP) or Curriculum 2006 are planned and implemented by the education unit, aimed to make schools autonomous. Arabic subjects as compulsory subjects taught religious school at all levels, starting from the Madrasah Ibtida'iah (MI), Madrasah Tsanawiyah (MTs) and Madrasah Aliyah (MA), including private madrasah (MAS) GUPPI in the City of Jambi. The focus of assessment in this study is to evaluate the implementation of intrinsic evaluation KTSP covering curriculum components and identify teachers' understanding of curriculum, planning, learning Arabic in MAS GUPPI Jambi city. Methods used in data collection is to use observation, interviews, and document analysis. Qualitative data were analyzed using an evaluation Stake's Model (Stake's Countenance Model-CSM), which consists of description matrix and judgement matrix. The results showed that the implementation of the MAS GUPPI KTSP Jambi City has done well. Starting from the operational readiness of human resources, planning documents KTSP, and also the ability of teachers in making the syllabus and Teaching Program Plan (RPP) in learning Arabic.
\end{abstract}

Keywords: KTSP, Curriculum of Education, Stake's Countenance Model, MAS GUPPI

Pendidikan merupakan aspek penting bagi perkembangan sumber daya manusia, kerana pendidikan merupakan instrumen yang digunakan bukan sahaja untuk membebaskan manusia dari keterbelakangan, akan tetapi juga membebaskan manusia daripada kebodohan dan kemiskinan. Pendidikan diyakini mampu menumbuhkan semangat bagi semua orang untuk mempelajari ilmu pengetahuan dan keterampilan yang baru sehingga memperolehi manusia yang produktif. Pada sisi lain pendidikan dipercayai mampu menjadi wahana perluasan akses dan mobiliti sosial dalam masyarakat sama ada secara horizontal mahupun vertikal. Masyarakat Indonesia dengan laju pembangunannya masih lagi menghadapi masalah pendidikan yang berat terutama dengan kaitannya dengan kualiti, relevansi dan keberkesanan pendidikan.

Untuk sentiasa menjaga keseimbangan kehidupan pendidikan yang terus bergerak secara dinamik, maka penilaian dilakukan untuk proses refleksi dari bahagian pelaksanaan kurikulum pendidikan. Dalam perkembangannya kurikulum di Negara Kesatuan Republik Indonesia sangatlah terpengaruh dengan keluarnya Undang-undang Nombor 20 tahun 2003 tentang Sistem Pendidikan Nasional, Peraturan Pemerintah Nombor 19 tahun 2005 tentang Standard Nasional Pendidikan, Peraturan Menteri Pendidikan Nasional (Permendiknas) Nombor 22 tahun 2006 tentang Standard Isi, Nombor 23 tentang Standard Kompetensi Lulusan, Nombor 24 tentang pelaksanaannya (Maliki \& Seosarno 2010).

1 Budi Sanjaya*(Corresponding author), Ph.D. Candidate at the Faculty of Education, Universiti Kebangsaan Malaysia, 43600 BANGI, Selangor, Malaysia, Email: budijaya81@gmail.com; Maimun Aqsha Lubis Ph.D., Assoc. Prof. at Dept. of Educational Methodology and Practice, Faculty of Education, Universiti Kebangsaan Malaysia, 43600 BANGI, Selangor, Malaysia, Email: draqsha@gmail.com. 
Kurikulum Tingkat Satuan Pendidikan (KTSP) yang dikenal pula dengan kurikulum 2006 yang diolah berdasarkan Standard Isi (SI0 dan Standard Kompetensi Lulusan (SKL) sebagai produk dari Badan Standard Nasional Pendidikan (BNSP) telahpun dirasmikan pada 7 Julai 2006 (Mulyasa 2006). Kurikulum ini pula mengisyaratkan dengan adanya otonomi daerah mahupun satuan pendidikan tersebut, membuat daerah-daerah di Indonesia berlumba untuk berinovasi dalam pengembangan kurikulum (curriculum development). Demikian halnya Kota Jambi yang merupakan salah satu kota besar di pulau Sumatera negara Indonesa (selain Medan, Palembang, dan Aceh) yang telah mampu melaksanakan autonomi dan sangat menunjang terlaksananya KTSP di sekolah mahupun madrasah. Dalam menjalankan proses pembelajaran berbasis satuan pendidikan, semua sekolah sama ada sekolah negeri mahupun swasta, peringkat Sekolah Dasar (SD) hingga ke Sekolah Menengah Atas (SMA) dan Madrasah Aliyah (MA) telah menerapkan KTSP ini termasuk di antaranya Madrasah Aliyah Swasta Gabungan Usaha Pembaruan Pendidikan Islam (GUPPI) yang merupakan satu dari sedikit MA swasta yang telah menerapkan KTSP.

Kementerian Pendidikan Nasional (2006) telah menyenaraikan mata pelajaran bahasa Arab sebagai mata pelajaran yang wajib diajarkan pada semua peringkat sekolah keagamaan mulai daripada Madrasah Ibtida'iah (MI), Madrasah Tsanawiyah (MTs) dan Madrasah Aliyah (MA), termasuklah Madrasah Aliyah Swasta (MAS) GUPPI yang berada di Kota Jambi. Penilaian kurikulum dalam upaya peningkatan hasil (output) sekolah adalah suatu realiti yang tak dapat dielakkan lagi bahawa itu menjadi salah satu tugas bagi sekolah dan pengamal pendidikan. Bahasa Arab di MAS GUPPI termasuk mata pelajaran inti yang harus dipelajari oleh siswa, dan dalam pelaksanaannya harus dinilai.

\section{Tinjauan Literatur}

Penilaian mengikut Joint committee (1981) ialah suatu kajian yang sistematik atau yang teratur tentang manfaat dan kegunaan beberapa objek. Purwanto \& Suparman mendefinisikan penilaian sebagai proses penerapan prosedur ilmiah untuk mengumpulkan data yang valid dan reliabel untuk membuat suatu keputusan. Mengikut Undang-undang Nombor 20 tahun 2003 dan Peraturan Pemerintah Nombor 19 tahun 2005 menetapkan kurikulum adalah sebagai satu set rancangan dan pengaturan mengenai tujuan, isi dan bahan pelajaran serta cara yang digunakan sebagai pedoman penyelenggaraan aktiviti pembelajaran untuk mencapai tujuan pendidikan tertentu.

Mengikut Fullan (1983) pelaksanan kurikulum adalah satu proses yang melibatkan penyertaan guru dan siswa secara berkesan dan bersifat kompleks. Pelaksanaan kurikulum pula apa sahaja yang dilaksanakan oleh guru dan siswa untuk mencapai hasil dalam persekitaran pembelajaran yang kondusif (Mackey 1988). Penilaian berfokus kepada upaya untuk menentukan tingkat perubahan yang terjadi pada hasil belajar (behaviour) (Tyler 1949). Ruang lingkup penilaian yang dikemukakan oleh Tyler memang sangat terhad jika dilihat dari perkembangan bidang kajian semasa ini. Fokus utama dari penilaian Tyler adalah pada hasil belajar secara umumnya diukur melalui tes, manakala pelaksanaan kurikulum diabaikan, sehingga model ini sering disebut dengan istilah black box. Manakala Attkinson (1978) pula berpendapat bahawa penilaian kurikulum adalah satu proses menilai kebekesanan, kecekapan dan kesempurnaan suatu kurikulum.

Dalam kaitannya antara penilaian dan kurikulum Cronbach (1980) dalam Hasan (2008) mengatakan penilaian adalah suatu proses yang sistematik untuk menentukan atau mengambil keputusan sampai sejauh mana tujuan kurikulum telah dicapai oleh siswa. Mengikut Hasan (2008) pula, penilaian kurikulum dan penilaian pendidikan memiliki karakteristik yang tidak dapat dipisahkan dari bidang kajian ilmu sosial pada umumya. Karakteristik itu adalah lahirnya pelbagai definisi untuk suatu istilah teknis yang sama, begitu pula dengan penilaian yang diertikan oleh para pakar dengan pelbagai pengertian. 
Kurikulum Tingkat Satuan Pendidikan (KTSP) adalah suatu idea tentang pengembangan kurikulum yang diletakkan pada kedudukan yang paling dekat dengan pembelajaran, iaitu sekolah atau satuan pendidikan. Secara umum tujuan diterapkannya KTSP adalah untuk memandirikan dan memperkasa satuan pendidikan melalui pemberian kewenangan (autonomi) kepada lembaga pendidikan dan menyokong sekolah untuk melakukan pengambilan keputusan secara partisifatif dalam pengembangan kurikulum (Mulyasa 2006). Komponen KTSP yang tercantum dalam dokumen kurikulum adalah: Tujuan satuan pendidikan (visi dan misi satuan pendidikan); Struktur dan muatan kurikulum; Muatan lokal; Beban belajar; Ketuntasan belajar; Kenaikan kelas dan kelulusan; Penjurusan; Standard kompetensi lulusan (SKL); Sukatan pelajaran, dan; Rancangan Program Pembelajaran (RPP).

Struktur dan muatan KTSP pada peringkat pendidikan dasar dan menengah yang tercantum dalam Standard Isi (SI) merangkumi lima kumpulan mata pelajaran iaitu: Kumpulan mata pelajaran agama dan akhlak mulia; Kumpulan mata pelajaran kewarganegaraan dan keperibadian; Kumpulan mata pelajaran ilmu pengetahuan dan teknologi; Kumpulan mata pelajaran estetika, dan; Kumpulan mata pelajaran jasmani, sukan, dan kesihatan. Kumpulan mata pelajaran tersebut dilaksanakan melalui muatan dan/atau aktiviti pembelajaran seperti dihuraikan dalam Peraturan Pemerintah (PP) no 19 tahun 2005 fasal 7, yang menyatakan bahawa muatan KTSP meliputi sejumlah mata pelajaran, muatan lokal dan aktiviti pengembangan diri yang keluasan dan kedalamannya merupakan beban belajar bagi siswa pada satuan pendidikan. Penilaian kurikulum dapat difokuskan kepada outcomes (hasil) dari kurikulum tersebut (outcomes based) dan juga dapat pada komponen kurikulum tersebut (intrinsic evaluation). Fokus penilaian intrinsik adalah seperti penilaian terhadap komponen kurikulum, penilaian terhadap sarana dan prasarana penyokong kurikulum, penilaian sumber manusia untuk menyokong kurikulum, dan karakteristik guru dan siswa yang menjalankan kurikulum tersebut.

\section{Model Stake's Countenance}

Model penilaian countenance dianggap model penilaian yang dianggap cukup memadai untuk menilai sebuah proses pelaksanaan pembelajaran secara kompleks. Model ini dikembangkan oleh Stake, kata countenance sendiri berasal dari ayat bahasa Inggeris yang mempunyai erti menyetujui atau persetujuan. Manakala secara ilmiah pula, istilah countenance bererti penilaian yang menekankan pelaksanaan deskripsi dan pertimbangan. Stake (1972) mendasarkan modelnya kepada penilaian formal, di mana dikatakannya sebagai suatu aktiviti yang sangat bergantung kepada penggunaan "checklist, structured visitation by peers, controlled comparisons, and standardized testing of students". Model Countenance Stake terdiri atasa dua matriks utama:

1. Matriks Deskripsi: Matriks deskripsi terdiri atas dua kategori iaitu yang pertama adalah sesuatu yang dirancang (intent) oleh pengembang kurikulum atau program. Kategori kedua adalah pengamatan (observation) iaitu yang berhubung dengan apa yang berlaku sesuai dengan apa yang dikehendaki dari kategori pertama. Kategori pengamatan ini terdiri dari : masukan (antecedants), proses (transaction), dan hasil (outcomes). Pada kategori kedua ini penilai harus melakukan pemerhatian untuk mendapatkan data tentang masukan (antecedants), proses (transaction), dan hasil (outcomes) yang ada pada satuan pendidikan.

2. Matriks Pertimbangan: Matriks pertimbangan terdiri atas kategori standard dan kategori pertimbangan, dan fokus dari masukan (antecedants), proses (transaction), dan hasil (outcomes). Standard adalah kriteria harus dipenuhi oleh suatu kurikulum atau program yang dijadikan evaluan. Standard tersebut dapat dikembangkan dari karakteristik yang dimiliki oleh kurikulum, tetapi dapat pula dikembangkan dari yang lain. Kategori kedua adalah kategori pertimbangan, pada kategori ini menghendaki evaluan melakukan pertimbangan dari apa sahaja yang telah dilakukan dari kategori pertama dan kedua dari 
matriks deskripsi dan kategori pertama dari matriks pertimbangan. Untuk lebih jelasnya dapat dilihat pada rajah berikut:

Rajah 1: Model Penilaian Stake's Countenance

\begin{tabular}{|c|c|c|c|c|c|}
\hline & Rancangan & Pemerhatian & \multirow[b]{2}{*}{ Masukan } & Standard & Pertimbangan \\
\hline a & & & & & \\
\hline i & & & Transaksi & & \\
\hline $\mathrm{a}$ & & & Hasil & & \\
\hline & \multicolumn{2}{|c|}{ Matriks Deskripsi } & & \multicolumn{2}{|c|}{ Matriks Pertimbangan } \\
\hline
\end{tabular}

Dalam model Stake ini, penilai (evaluator) tidak hanya mengerjakan matriks Deskripsi dan matriks Pertimbangan sahaja, akan tetapi juga mencari contigency dan kesesuaian (congruence) dari data yang telah diperoleh. Contigency terdiri atas contigency logik dan contigency empirikal. Contigency logik adalah hasil pertimbangan penilai terhadap kesesuaian logik antara masukan dengan proses dan hasil. Ini adalah pertimbangan pertama yang harus dilakukan oleh penilai. Selanjutnya penilai pula, memberikan pertimbangan empirik (empirical contigency) berdasarkan data yang diperoleh di tempat kajian, antara masukan, proses dan hasil. Selain mencari contigency, penilai kemudian memberikan pertimbangan mengenai congruence atau perbezaan yang berlaku antara apa yang dirancang dengan apa yang sebenarnya berlaku dalam kajian. Untuk lebih jelasnya cara kerja dari model Stake ini dapat dilihat dari Rajah 2 iaitu Cara Kerja Model Penilaian Stake's Countenance:

Rajah 2: Cara Kerja Model Penilaian Stake's Countenance

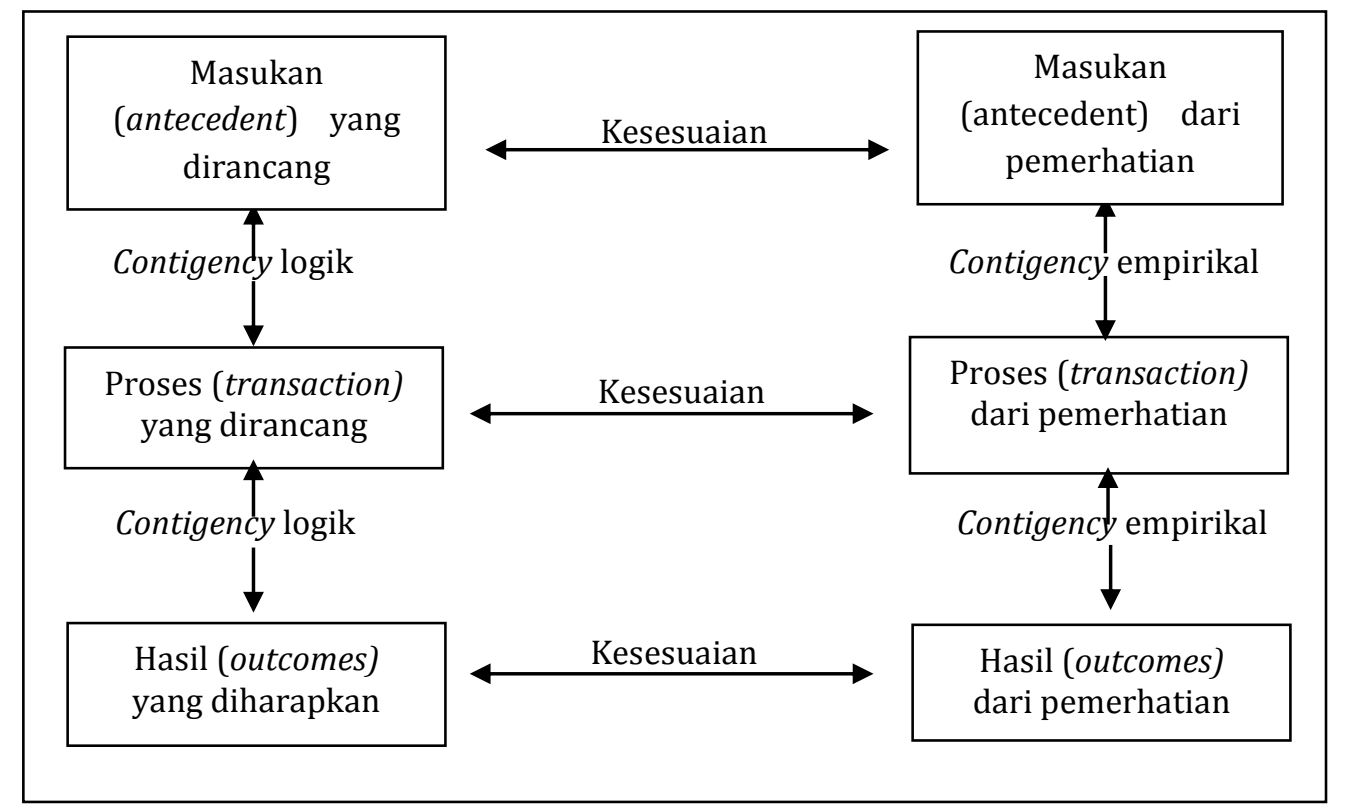


Sama seperti mata pelajaran bahasa yang lainnya, mata pelajaran bahasa Arab pula adalah mata pelajaran yang mengembangkan empat kemahiran berbahasa iaitu: kemahiran istima' (mendengar), kemahiran kalam (bertutur), kemahiran kitabah (menulis) dan kemahiran qira'ah (membaca) (DEPAG 2008). Mata pelajaran bahasa Arab di Madrasah Aliyah di Indonesia mempunyai tujuan agar para siswa mampu mengembangkan diri dalam hal:

1. Mengembangkan kemahiran berkomunikasi dalam bahasa Arab, sama ada secara lisan mahupun tulisan yang mencakupi empat kemahiran berbahasa iaitu istima' (mendengar), kemahiran kalam (bertutur), kemahiran qira'ah (membaca) dan kemahiran kitabah (menulis).

2. Menumbuhkan kesedaran tentang pentingnya bahasa Arab sebagai salah satu bahasa asing untuk menjadi alat utama belajar, khususnya dalam mengkaji sumber-sumber ajaran Islam.

3. Mengembangkan pemahaman tentang kaitan antara bahasa dan budaya serta memperluas cakerawala budaya dan melibatkan diri dalam keragaman budaya.

\section{Kaedah Kajian Penilaian}

Pendekatan kajian penilaian yang digunakan untuk mengkaji pelaksanaan Kurikulum Tingkat Satuan Pendidikan (KTSP) pada mata pelajaran bahasa Arab di MAS GUPPI Kota Jambi adalah dengan kaedah kualitatif dan teori Stake's Countenance Model. Pengambilan data secara target sampling, teknik pengumpulan trangulasi (gabungan), analisa data bersifat induktif/kualitatif, dan hasil kajian kualitatif lebih menekankan kepada generalisasi. Kaedah kajian yang dijalankan dalam kajian ini adalah penelitian penilaian kualitatif, kerana pada permasalahannya belum jelas, holistik, dinamik, dan penuh makna sehingga tidak mungkin data pada situasi sosial tersebut diperoleh dengan kaedah situasi sosial kuantitatif, dan instrumen kajian dalam kajian ini adalah protokol temu bual dan checklist pemerhatian.

Analisis berdasarkan model penilaian Stake's Countenance adalah Contigency yang terdiri dari contigency logik dan contigency empirik. Contigency logik adalah hasil pertimbangan penilai terhadap keterkaitan atau kesesuaian logik antara kotak masukan (antecedants), proses (transaction), dan hasil (outcomes). Penilai pula memberikan pertimbangan keterkaitan empirik, berdasarkan data kajian, antara masukan (antecedants), proses (transaction), dan hasil (outcomes) mengenai congruence (keselarasan) atau perbezaan yang terjadi pada apa yang dikerjakan dengan apa yang terjadi pada tempat kajian. Cara kerja model penilaian Stake ini adalah; penilai mengumpulkan data mengenai apa yang diinginkan oleh pengembang program sama ada yang berkaitan dengan keadaan awal (antecedants), proses (transaction) dan hasil (outcomes). Data dapat dikumpulkan sama ada melalui dokumen ataupun temu bual.

\section{Hasil Kajian}

Madrasah Aliyah Swasta (MAS) GUPPI terletak di Jalan Jend. Sudirman, Kelurahan Pakuan Baru, Kecamatan Jambi Selatan, Kota Jambi. Madrasah ini didirikan pada tahun 1987 yang dipelopori oleh Bapak Drs.Hj. M. Arfah Hap, MM. Madrasah Aliyah GUPPI ini mempunyai visi iaitu unggul dalam IMTAQ (iman dan takwa), IPTEK (ilmu pengetahuan dan teknologi) dan Akhlak Mulia. Madrasah Aliyah GUPPI ini mampu menampung lebih kurang 250 orang siswa yang dididik oleh 22 orang tenaga pengajar (guru), dan 95\% guru telah mendapat ijazah sarjana dalam bidang masing-masing.

MAS GUPPI telah merintis pelaksanaan KTSP sejak tahun pelajaran 2006/2007 dan mulai memberlakukan KTSP sejak tahun pelajaran 2009/2010. Pengurusan pendidikan yang terancang, terarah, dan berterusan ini merupakan bentuk dari pelaksanaan UU No. 20 tahun 2003 serta PP No. 19 tahun 2005. Panduan pendidikan dari pusat dan Majelis Pendidikan yang menjadi acuan MAS GUPPI dalam mengembangkan Kurikulum Tingkat Satuan Pendidikan. 


\section{Analisis Model Penilaian Stake's Countenance}

Keseluruhan konsep Countenance adalah Contigency dan kesesuaian, di mana penilai membandingkan keadaan pada tahap rancangan dengan proses pelaksanaannya, sehingga memberikan pertimbangan dan hasil yang sedia ada.

\section{Masukan (Antecedants)}

1. Tujuan KTSP MAS GUPPI adalah mewujudkan siswa yang unggul dalam IMTAQ (iman dan taqwa), IPTEK (ilmu pengetahuan dan teknologi) dan Akhlak Mulia.

2. Struktur dan muatan kurikulum dirancang dengan 5 (lima) kumpulan mata pelajaran iaitu kumpulan mata pelajaran Agama Islam dan Akhlak Mulia, Kewarganegaraan dan Keperibadian, Ilmu Pengetahuan dan Teknologi, Estetika serta Jasmani, Sukan dan Kesihatan.

3. Mata pelajaran bahasa Arab yang dilaksanakan merupakan mata pelajaran wajib yang diajarkan pada peringkat pendidikan yang bercorak keagamaan.

4. Beban belajar yang dilaksanakan menggunakan "sistem pakej" iaitu sistem penyelenggaraan program pendidikan yang siswanya diwajibkan mengikuti semua program pembelajaran dan beban belajar setiap mata pelajaran dinyatakan dalam satuan jam pembelajaran.

5. Ketuntasan belajar MAS GUPPI dalam menentukan Kriteria Ketuntasan Minimum (KKM) dengan mempertimbangkan peringkat kebolehan purata siswa, kerumitan (kompleksitas) kompetensi, serta kemampuan sumber daya penyokong dalam pembelajaran.

6. Kenaikan kelas, kelulusan dan penjurusan. Kenaikan dilaksanakan pada akhir tahun pelajaran dengan kriteria sesuai KKM. Kriteria kelulusan dilakukan setelah menyelesaikan semua program pembelajaran dan mengikuti semua peperiksaan sekolah dan peperiksaan nasional (UN).

7. Standard Kompetensi Lulusan (SKL), pada mata pelajaran bahasa Arab ada 4 (empat) SKL yang dirancang iaitu mampu dan boleh mendengarkan, bertutur, membaca, dan menulis dalam bentuk wacana kehidupan sehari-hari di rumah, sekolah dan persekitaran.

8. Sukatan pelajaran, mengembangkannya dari apa sahaja yang telah menjadi ketentuan dari SKL yang ditetapkan secara kendiri.

9. Rancangan Program Pembelajaran (RPP) dijabarkan melalui sukatan pelajaran yang telah dikembangkan.

\section{Proses (Transaction)}

1. Menentukan tujuan pendidikan berdasarkan visi MAS GUPPI dan Permendiknas no. 22, 23 dan 24 tahun 2006.

2. Dari struktur kurikulum yang ada, menambahkan jam pembelajaran mata pelajaran Pendidikan Agama Islam (PAI) yang semula 2 (dua) jam pelajaran menjadi 4 (empat) jam pelajaran, mata pelajaran bahasa Arab yang semula 2 (dua) jam pelajaran juga menjadi 4 (empat) jam pelajaran.

3. Bahasa Arab menjadi mata pelajaran yang wajib dipelajari pada peringkat pendidikan yang bercorak agama, sejak berdirinya MAS GUPPI ini telah menjadikan mata pelajaran ini sebagai mata pelajaran yang wajib dipelajari.

4. Beban belajar, hari belajar siswa adalah 6 (enam) hari iaitu mulai hari Isnin hingga hari Sabtu. Jumlah jam pelajaran siswa adalah 45 jam pelajaran setiap mata pelajaran.

5. Ketuntasan belajar siswa, pada mata pelajaran bahasa Arab dalam satu semesternya khususnya di semester genap tahun pelajaran 2012/2013 telah menyelesaikan apa yang menjadi standard pedoman SKL, iaitu mendengar, bertutur, membaca dan menulis.

6. Kenaikan kelas, semua mata pelajaran yang telah dilewati, mulai program perencanaan hingga program remedial, dari semua siswa tingkatan X (sepuluh) lulus bahasa Arab 100\% dan dikatakan lulus. 
7. Sukatan pelajaran dan RPP, garis-garis rancangan pembelajaran yang sudah tercantum di atas kertas dam masuk dalam dokumen KTSP MAS GUPPI Kota Jambi telah menjadi landasan awal guru dalam membelajarkan siswa di bilik darjah. Standard Isi (SI) juga telah selari dengan apa yang dirancang.

\section{Hasil (Outcomes)}

1. Melihat apa yang telah dirancang hingga kepada proses yang telah dilaksanakan, tahap perancangan yang baik serta proses yang berjalan hampir tidak dijumpai kekangan yang bererti.

2. Berdasarkan hasil pengamatan, peneliti menemukan hasil dalam pelaksanaan kurikulum di MAS GUPPI Kota Jambi termasuk sangan mampu, kerana dari sisi pengurusan serta pelaksana yang tersedia, pembiayaan, sarana dan prasarana, perancangan hingga penilaian perkembangan kurikulum, sekolah dapat dikategorikan telah sedia melaksanakan.

3. Dalam keseharian menjalankan proses pembelajaran, semua elemen sekolah (guru dan siswa) merasa tiada kekangan dengan program dan isu yang ada.

4. Sama ada guru, siswa, dan pegawai pentadbiran, hampir tiada yang merasa tertekan dari pihak luar, sama ada itu faktor dari dalam sekolah, pentadbiran mahupun keadaan sosial ekonomi persekitaran sekolah. Kerana satuan pendidikan (sekolah) telah merancang dengan sungguh-sungguh apa-apa sahaja yang akan menjadi masalah dalam proses pelaksanaan.

5. Dengan pencapaian yang ada, satuan pendidikan mampu menjalin hubungan baik dengan pihak luar sebagai rakan kerja.

Berdasarkan kajian penilaian terhadap pelaksanaan Kurikulum Tingkat Satuan Pendidikan (KTSP) pada mata pelajaran bahasa Arab di MAS GUPPI Kota Jambi, maka dapat disimpukan bahawa pelaksanaan (KTSP) di MAS GUPPI Kota Jambi sebagai bentuk operasional kurikulum dilaksanakan secara kendiri dan dikembangkan dengan memperhatikan potensi dan karakteristik daerah/wilayah sekolah, termasuk isi dari KTSP iaitu menuju sekolah yang autonomi.

Kesediaan sekolah MAS GUPPI Kota Jambi dalam melaksanakan KTSP berdasarkan Sumber Daya Manusia, pembuat kebijakan (pengetua sekolah, pengetua sekolah bahagian kurikulum, dan pengawas sekolah), sarana dan prasarana, dan lain sebagainya dapat dikatakan telah siap melaksanakan KTSP. Hal ini dapat dilihat dari pelaksanaannya mulai dari perancangan hingga kepada penilaian dan pengawasan oleh lembaga penjamin mutu, iaitu bidang kuriulum dalam masa satu Kompetensi Dasar (KD) selesai dalam empat kali perjumpaan. Kebolehan guru mata pelajaran bahasa Arab dalam menjabarkan dan mengembangkan sukatan pelajaran ke dalam Rancangan Program Pembelajaran (RPP) dilakukan secara kendiri.

\section{References}

Attkinson, C.C. 1978. Evaluation of Human Service Program. New York: Academic Press.

Cronbach, L.J. 1983. Essentials of Psychological Testing. New York: Harper \& Row.

Depag. 2008. Standar Isi dan Kompetensi Lulusan Mata Pelajaran Pendidikan Islam dan Bahasa Arab. Jakarta: Permenag No. 02 tahun 2008.

Depdiknas. 2006. Peraturan Pemerintah, Nombor 19 Tahun 2005. Tentang Standar Nasional Pendidikan.

Depdiknas. 2006. Standar Isi. Jakarta : Permendiknas No. 22 Tahun 2006.

Depdiknas. 2006. Standar Kompetensi Lulusan. Jakarta: Permendiknas No. 23 Tahun 2006.

Depdiknas. 2006. Pelaksanaan Standar Isi dan Kompetensi Lulusan. Jakarta: Permendiknas No. 24 tahun 2006. 
Hasan, S.H. 2008. Evaluasi Kurikulum. Bandung: Sekolah Pascasarjana Universitas Pendidikan Bandung.

Mackey, T.P. \& Jacobson, T.E. 2010. Collaborative Information Literacy Assessment : Strategies for Evaluating Theaching and Learning. New York: Neal-schuman Publishers, Inc.

Maliki, \& Soesarno, L.H. 2010. Evaluasi Pelaksanaan Kurikulum Tingkat Satuan Pendidikan (KTSP) Suatu Penelitian Evaluasi berdasar Stake's Countenance Model mengenai KTSP Pada Muatan Lokal Bahasa Mandarin di SMA Muhammadiyah 2 Surabaya 2009/2010. Jurnal Teknologi Pendidikan Universitas Negeri Surabaya 10: 38-46

Purwanto, Ngalim. 2004. Prinsip-prinsip dan Teknik Evaluasi Pengajaran. Bandung: PT Remaja Rosdakarya.

Stake, R.E. 1978. Program Evaluation Particularry Responsive Evaluation. Paper presented at a Conference on New Trend in Evaluation, Goteborg, Sweden, October 1973.

Tyler, T.W. 1949. Basic Principles of Curriculum and Instruction. Chicago: University of Chicago Press. 